Online: http://journal.uny.ac.id/index.php/jppfa

\title{
MENGHINDARI KEKERASAN DALAM PENGELOLAAN KARAKTER SISWA
}

\author{
Yulianto Hadi \\ Program Pascasarjana, Universitas Negeri Yogyakarta \\ yulianto.hadi@yahoo.com
}

\begin{abstract}
Abstrak
Artikel ini bertujuan untuk menelaah, mengetahui, dan memahami pengelolaan pendidikan karakter, kususnya bagi siswa SMA dan sederajat. Artikel ini merupakan kajian terhadap kondisi nyata yang berkembang di dunia pendidikan Indonesia, kususnya mengenai pengelolaan karakter siswa. Simpulan dari kajian ini adalah sebagai berikut: (1)edukasi dan pembentukan karakter terhadap anak yang dilakukan di sekolah, kelompok, dan masyarakat sosial hendaknya menghindari pemaksaan kehendak dengan segala bentuk abuse; (2) pembentukan karakter yang salah satunya diprogramkan oleh pemerintah dengan menitipkan di instansi/lembaga militer perlu dikaji ulang secara mendalam; (3) proses pendidikan dan pengelolaan karakter akan lebih berhasil apabila mengikuti beberapa tahapan pengelolaan kesadaran integral.
\end{abstract}

Kata kunci: kekerasan, dan pengelolaan karakter.

\section{AVOIDING ABUSE IN MANAGING THE STUDENTS' CHARACTER}

Yulianto Hadi

Program Pascasarjana, Universitas Negeri Yogyakarta

yulianto.hadi@yahoo.com

\section{Abstract}

This article aims to know, discover, and comprehend the character education management, especially of senior high school students and of those at the same level. This article is a study of the factual condition in Indonesian education, especially in managing the students' characters. The conclusions of the study are: 1) education and character formation of the students in school, group/party, and social communities may avoid coercion of one's desire, in every form of abuse; 2) character formation programmed by the government by sending students to the military agency needs to be re-examined deeply; 3) education process and character management will be successful if it follows several stages of integral consciousness management.

Keywords: abuse and character management 



\section{PENDAHULUAN}

Rumusan tujuan sistem pendidikan nasional Indonesia sesuai dengan Pancasila dan Undang-Undang Dasar Tahun 1945, tertuang dalam UU RI Nomor 20 Tahun 2003 tentang Sistem Pendidikan Nasional. Pendidikan nasional berfungsi mengembangkan kemampuan dan membentuk watak serta peradaban bangsa yang bermartabat dalam rangka mencerdaskan kehidupan bangsa, bertujuan untuk mengembangkan potensi peserta didik agar menjadi manusia yang beriman dan bertaqwa kepada Tuhan Yang Maha Esa, berahlak mulia, sehat, berilmu, cakap, kreatif, mandiri, dan menjadi warga Negara yang demokratis serta bertanggung jawab. Ki Hajar Dewantara telah menyampaikan konsepsi Pendidikan, bahwa pendidikan sebagai daya upaya untuk memajukan budi pekerti, pikiran serta jasmani anak, agar dapat memajukan kesempurnaan hidup yaitu hidup yang selaras dengan alam dan masyarakatnya. Dari formulasi konsepsi makna pendidikan tersebut, terdapat substansi yang sangat penting yaitu mengembangkan potensi/kemampuan peserta didik, dan membentuk budi pekerti. Selain mengembangkan potensi akademis, psikomotorik, dan jasmani/kesehatan, juga harus mengembangkan dan membentuk budi pekerti sesuai dengan budaya bangsa. Untuk itu setiap lembaga pendidikan selain mengembangkan kurikulumnya secara terusmenerus, juga harus mengarahkan dan mengendalikan budi pekerti peserta didik supaya tetap memiliki kepribadian dan karakter yang sesuai dengan budaya bangsa.

Semakin berkembangnya kurikulum, tuntutan penguasaan materi akademis semakin tinggi dan semakin berat. Banyak pakar berpendapat bahwa sebagai konsekuensi diberlakukannya Standar Nasional Pendidikan Indonesia, kurikulum terfokuskan pada aspek akademis, sehingga sering tanpa disadari menjadi melupakan pembinaan budi pekerti. Secara positif diakui bahwa dari sisi kognitif sangat banyak kemajuan yang telah diraih. Tetapi, bagaikan ungkapan "nobody's perfect" bahwa kemajuan yang diperoleh belum menjadikan kesempurnaan bagi setiap peserta didik. Berbagai kekerasan telah melanda banyak siswa di berbagai daerah. Tahun yang silam kejadian tewasnya siswa di Jakarta karena perkelahian antarpelajar, berbagai kekerasan dari tenaga pendidik terhadap siswanya, terjadinya pelecehan seksual terhadap para siswa, dan terjadinya perkosaan dan pembunuhan terhadap seorang siswi SMK, itu semua merupakan bukti yang tidak sedap bagi komunitas pendidikan. Ada masalah apa dengan pendidikan nasional, apakah kurikulumnya, apakah operasional pendidikannya, apakah aspek pendidiknya, ataukah lingkungannya, dan bagaimana dengan keluarga? Semua persoalan itu perlu ditelaah secara cermat.

Masalah pendidikan karakter telah menjadi isu yang sangat populer pada beberapa tahun terakhir. Banyak persoalan di dalamnya, seperti masalah bullying, atau abuse yang terjadi dimana-mana. Pemerintah telah melakukan berbagai upaya untuk mengatasi persoalan pendidikan karakter. Seperti keakraban antarsekolah dengan program pertukaran Pembina Upacara dan dialog bersama antarsiswa lain sekolah. Beberapa tahun terakhir pemerintah telah melaksanakan program Pendidikan Dasar Kepemimpinan yang pelaksanaannya dikemas semacam Pendidikan Dasar Kemiliteran. Program tersebut dilaksanakan di lembaga pendidikan militer dan sebagai pelakunya adalah dari anggota/instruktur militer. "Model" program tersebut banyak ditiru dan dilakukan oleh berbagai pengelola sekolah. Lalu bagaimana hasilnya, apakah ada perubahan positif terhadap karakter siswa, apakah hasilnya signifikan? Model tersebut perlu dicermati lagi, beberapa hal yang perlu diperhatikan diantaranya adalah kenalnya anak terhadap kekerasan dalam istilah lain sering disebut dengan abuse.

Pengelolaan karakter dan budi pekerti peserta didik diperlukan waktu yang cukup panjang, bahkan sampai setelah mereka lulus dari sekolahpun tetap memerlukan pengelolaan. Budi pekerti merupakan edukasi sepanjang hayat manusia. Untuk itu naskah yang berjudul "Menghindari Kekerasan dalam Pengelolaan Karakter" menyampaikan sedikit mengenai beberapa hal yang perlu dicermati dalam mengelola karakter peserta didik. Diantaranya mengenai nilai-nilai kehidupan, dinamika sosial, proses penanaman nilai, dan proses perubahan perilaku. Beberapa hal tersebut sangat diperlukan dalam pengelolaan karakter dan budi pekerti peserta didik. Volume 4, Nomor 1, Juni 2016 


\section{PEMBAHASAN}

\section{Abuse}

Kekerasan atau abuse dalam bentuk apapun dapat terjadi dimanapun, dan sering tanpa disadari oleh pelaku. Hal tersebut bukan hanya di sekolah, tetapi dapat terjadi di rumah, di masyarakat dan di tempat lain. Tidak disadari oleh orang yang lebih dewasa bahwa hampir setiap hari mengenalkan dan mengajarkan abuse atau kekerasan kepada yang lebih muda. Abuse dapat berupa verbal abuse, physical abuse, emotional abuse, bahkan sexual abuse. Kekerasan dapat menimbulkan berbagai resiko, diantaranya timbul rasa khawatir yang berlebihan, rasa rendah diri, depresi, trauma, melukai diri sendiri atau balas dendam pada orang lain. Dampak psikis atau mental sering disebabkan karena verbal abuse. Dengan dalih untuk mendidik, verbal abuse banyak terjadi di keluarga ataupun di sekolah. Hal tersebut merupakan paradoks di dunia pendidikan yang semestinya terlaksana dengan penuh kasih sayang. Apabila setiap hari peserta didik mendengar, melihat, merasakan, dan menjalani abuse, maka besar kemungkinan abuse terbentuk dalam dirinya menjadi karakter dan budaya.

Analisi terhadap permasalahan abuse seolah terjadi dehumanisasi, pendidikan telah kehilangan sebuah sentuhan kemanusiaan dan rasa kasih sayang. Metodologi pendidikan dan praksis pendidikan perlu dikaji ulang secara lebih teliti. Diharapkan dalam proses pembelajaran dan pendidikan, anak tidak akan kehilangan peran dalam perkembangan jiwanya, baik melalui pendidikan di sekolah maupun melalui kehidupan di sosial masyarakat. Pada saat tertentu "mungkin" abuse dibutuhkan, namun alangkah lebih baiknya apabila proses pembelajaran kehidupan yang dilakukan di sekolah maupun di lingkungan keluarga, dan masyarakat sosial dapat dihindarkan dari abuse dalam bentuk apapun.

Dalam pelaksanaan pendidikan karakter harus lebih hati-hati, karena peserta didik setingkat SMA/SMK merupakan masa adolesensi yang penuh dengan gejolak jiwa. Masa pertumbuhan jiwa, pertumbuhan rasa kebanggan diri, terbentuknya rasa percaya diri, dan membutuhkan pengakuan diri dari orang/pihak lain. Tetapi di sisi lain harus dikembangkan altruist-nya sehingga mereka selain berkembang potensi kejiwaan dirinya, diharap- kan juga dengan ikhlas dapat menerima hadirnya orang/pihak lain dalam segala aspek kehidupannya. Dengan demikian tidak akan terjadi gesekan-gesekan, pertentangan-pertentangan dalam kehidupannya. Diperlukan penjelasan yang mendalam tentang perilaku dan pembinaan yang terus-menerus setiap hari. Sehingga anak faham terhadap nilai-nilai filosofis perilaku yang diajarkan padanya.

\section{Nilai-Nilai Kehidupan}

Manusia hidup tidak akan lepas dari kelompok, lingkungan dan masyarakatnya, karena manusia diciptakan sebagai makhluk sosial yang hidup berkelompok. Setiap kelompok memiliki norma dan aturan yang harus dikuti oleh anggotanya. Norma berasal dari kesepahaman dan kesepakatan yang diterima oleh kelompok. Kesepakatan berawal dari kesamaan cara pandang, dan cara pandang merupakan hasil dari persepsi individu. Hakikat apa yang menjadi tujuan hidup, bagaimana pandangan terhadap hidupnya, itulah nilai kehidupannya. Nilai kehidupan berawal dari persepsi individu yang berkembang di keluarganya. Individu-individu masuk dalam kelompok dengan gagasan yang sudah terkonsep sebelumnya dalam diri mereka. Gagasan tersebut terseleksi dalam kelompok dan organisasi menjadi mana yang benar dan mana yang salah, maka teridentifikasilah suatu nilai organisasi. Dalam konteks ini manusia sebagai manusia individual dan manusia organisasional, Kabul Budiyono (2007, p. 71).

Nilai-nilai kehidupan dapat berasal dari berbagai sumber. Dijelaskan oleh Rahmat Mulyana bahwa nilai diciptakan, dibentuk, dikembangkan dari suatu peristiwa, kejadian, sikap perilaku tokoh yang dianggap baik dan bermanfaat bagi individu dan masyarakat yang kemudian diwariskan dari generasi ke generasi melalui keteladanan dan pendidikan baik formal, nonformal dan informal, (2004: p. 24). Nilai-nilai yang diyakini oleh individu dalam masyarakat berasal dari lingkungan masyarakat itu sendiri. Nilai adalah gambaran mengenai apa yang diinginkan, pantas, berharga, dan mempengaruhi perilaku sosial orang-orang yang memiliki nilai tersebut. Nilai sosial merupakan landasan bagi masyarakat untuk merumuskan apa yang benar dan penting, memiliki ciri-ciri tersendiri, dan berperan penting untuk mendorong dan mengarahkan individu agar berbuat sesuai norma 
yang berlaku. Nilai bersumber dari masyarakat, kebiasaan dan folkways kemudian berkembang menjadi adat dan terpatri menjadi nilai serta norma yang harus diikuti dan dipatuhi oleh setiap anggota masyarakat. Nilai juga bersumber dan berkembang dari keluarga, Keith Patching (2007, p. 33) pada bukunya yang berjudul Leadership, Character and Strategy menjelaskan:

The values you hold are a key part of you see yourself. Until recently scientists belived that our value set is learnt from our parents. Lebih lanjut disampaikan: when you describe somebody as having a certain personality, you are intending to refer to some intrinsic part of their nature that beyond the influence of other peoplethe content of their character, to borrow a famous phrase. By definition, you mean something unique to them. It is, however, counter-intuitive after a century of Freudian certainties to find out how little that intrinsic character is influenced by the family they grew up in.

Karakter dan budi pekerti peserta didik sangat dipengaruhi oleh nilai-nilai kehidupan yang berkembang di keluarga dan di masyarakat. Lalu bagaimana dengan pendidikan nasional? Di manakah posisi lembaga pendidikan, dan apa peran lembaga pendidikan? Mengapa sekolah atau lembaga pendidikan sering dikambinghitamkan apabila terjadi perkelahian antarsiswa? Apa yang salah dengan pendidikan? Berbagai pertanyaan dilontarkan oleh berbagai pihak. Pantaskah lembaga sekolah disalahkan, ataukah hal itu hanya menjadi tanggungjawab sekolah saja? Tentunya tidak. Sedangkan tujuan pendidikan nasional secara filosofis mencakup aspek religius, humanisme, dan idealisme, yang secara praksis dikelompokkan menjadi tiga aspek utama yaitu aspek kognitif, afektif, dan psikomotorik. Sering disuarakan oleh berbagai kalangan dan berbagai pihak bahwa pendidikan hendaknya menjalankan proses pembelajaran yang transformatif dan partisipatif. Diharapkan dengan pola pembelajaran tersebut menjadikan siswa dan situasi hidup peserta didik sebagai titik tolak proses pembelajaran.

Pendidikan diharapkan bukan hanya masalah knowledge saja. Tetapi pendidikan adalah persoalan untuk mengusahakan agar pengetahuan dan nilai-nilai kehidupan dapat di batinkan dan dijadikan menyatu dengan diri peserta didik, sehingga akan berpengaruh terhadap cara berpikir, cara merasa, dan cara bertindak. Pada dasarnya peserta didik merupakan individu yang telah memiliki dan membawa sistem nilai. Mereka memiliki perasaan, keinginan, harapan, dan kenangan tersendiri. Untuk itu kepada peserta didik perlu adanya ruang kebebasan berekspresi dan berkreasi sehingga ide-ide dan inovasi-inovasi yang original dapat tereksplorasi, (Bambang, 2008, p. 354). Proses pembelajaran dalam pendidikan tidak cukup dengan klasikal saja. Ada beberapa metode lain yang dibutuhkan, seperti learning by doing and exposure, learning by experiencing, learning by exploring and appreciating, atau learning by living in.

Pemaknaan pendidikan tersebut cenderung selaras dengan pemikiran idealisme yang menyebutkan bahwa edukasi adalah sebuah proses menggali bakat-bakat terpendam pada anak. Pemikiran yang berpendapat bahwa guru sebagai seorang guru dalam moral, kultur, serta sebagai teladan, pada dasarnya berasal dari filsuf idealisme. Metode edukasi idealis dirancang untuk menstimulasi intuisi dan eksplorasi introspeksi diri secara mandiri pada pelajar. Proses perkembangan bersifat dari dalam ke luar. Tidak ada suatu metode pun yang digunakan secara khusus untuk menstimulasi pelajar. Bahkan, seorang guru idealis harus mampu menguasai berbagai macam metode dan menggunakan metode tertentu yang paling efektif untuk menjamin hasil yang diharapkan.

Beberapa konsep yang didasarkan pada filsafat idealisme memiliki relevansi tinggi pada praktek edukatif antara lain adalah suatu proses penyingkapan sesuatu yang tersembunyi pada manusia. Belajar adalah suatu proses pencarian untuk menstimulasikan pelajar agar menggali kebenaran yang ada dalam pikirannya. Guru menjadi teladan atas nilainilai moral dan kultural yang merepresentasikan ekspresi-ekspresi terbaik dari perkembangan kepribadian. Untuk itu dalam kehidupan di sekolah maupun di kelompok sosial masyarakat hendaknya berusaha keras menghindarkan anak dari abuse. Jangan sampai terbentuk persepsi dalam diri anak bahwa abuse dibenarkan dalam proses edukasi. Hindarkan terbentuknya persepsi bahwa abuse adalah bagian dari nilai-nilai kehidupan yang 
perlu di lestarikan. Sebaiknya dimunculkan gerakan kasih sayang dalam segala bentuk kegiatan edukasi, sehingga akan terbentuk suasana yang kondusif.

Dari beberapa uraian tersebut terungkap bahwa nilai-nilai kehidupan berasal dari keluarga, lingkungan, kelompok, masyarakat, dan agama. Nilai-nilai yang dianggap positif, baik dan dapat diterima oleh masyarakat akan menjadi norma masyarakat. Nilai-nilai kehidupan itulah yang melalui pendidikan akan di batinkan dan dijadikan menyatu dengan diri peserta didik, sehingga akan berpengaruh terhadap cara berpikir, cara merasa, dan cara bertindak. Sehingga pendidikan bertugas mengusahakan agar pengetahuan dan nilainilai kehidupan dapat dimiliki dan menyatu dalam diri peserta didik. Karena peserta didik merupakan individu yang telah memiliki perasaan, keinginan, harapan, dan kenangan tersendiri, maka kepada peserta didik sebaiknya diberikan ruang kebebasan berekspresi dan berkreasi sehingga ide-ide dan inovasiinovasi yang original dapat tereksplorasi secara optimal. Tetapi apakah metode dan pemaknaan pendidikan tersebut akan statis, sedangkan zaman bergeser terus-menerus yang mempengaruhi perubahan nilai-nilai kehidupan? Lebih lanjut tentang perubahan-perubahan tersebut akan diurai pada pembahasan dinamika sosial.

\section{Dinamika Sosial}

Dalam kehidupan sosial setiap nilai tidak akan memiliki arti yang konstan sepanjang masa, tetapi nilai akan selalu bersifat dinamis. Nilai akan selalu berubah seiring dengan perkembangan yang terjadi. Makna dari nilai tertentu pada zaman sekarang berbeda dengan makna nilai pada zaman dahulu meskipun objeknya sama. Perubahan-perubahan akan selalu terjadi, demikian pula pada proses penanaman nilai. Pada masa tertentu persepsi individu maupun kelompok terhadap makna dari nilai akan berubah-ubah, begitu pula terhadap nilai yang diberlakukan dan yang bisa diterima oleh kelompok. Pewarisan nilai juga tidak terlepas dari berbagai pengaruh, tentu akan terjadi pasang surut dan terjadi dinamika dalam prosesnya. Baik jangka waktu tahunan, lima tahunan, dekade atau ratusan tahun. Dinamika itu tentunya sesuai dengan perkembangan dan perubahan yang terjadi pada kondisi kelompok atau masyarakat itu sendiri. Perubahan-perubahan itu pada umumnya akan dipengaruhi oleh beberapa faktor, diantaranya yaitu politik, kebijakan, ekonomi, sosial, dan budaya.

Perubahan politik pada suatu negara akan membawa dampak yang sangat signifikan terhadap segala aspek kehidupan rakyatnya. Semakin radikal perubahan politik itu maka akan semakin ekstrim juga dampaknya. Pendidikan dalam tata pemerintahan tidak jarang dimanfaatkan sebagai media politik oleh pihak penguasa. Berbagai perubahan sistem dan kurikulum sering tidak sampai masuk ke ranah filosofis, tetapi cenderung terbatas pada tindakan taktis pragmatis sebagai media politik yang populer. Padahal justru tindakan yang pragmatis pada bidang pendidikan akan sangat membahayakan kehidupan rakyat pada jangka panjang. Karena pendidikan memiliki dampak yang sangat besar terhadap kehidupan pribadi, lingkungan, masyarakat, dan negara. Kebijakan politik akan menggerakkan aspek kehidupan lainnya. Perubahan politik dan kebijakan akan berdampak terhadap susunan atau struktur sosial masyarakat maupun budayanya, dan berdampak juga terhadap perkembangan perekonomian, (Ritzer, 2004, p. 7). Setiap perubahan politik akan diikuti oleh adanya perubahan pemberlakuan nilai-nilai. Baik nilai-nilai utama dari ideologi negara itu maupun nilainilai kehidupan pada aspek yang lain.

Pendidikan adalah salah satu media pewarisan nilai-nilai kehidupan dan pendidikan adalah media untuk meningkatkan daya pikir dan logika peserta didik. Manusia setelah mengikuti pendidikan akan meningkat daya persepsinya, dengan meningkatnya daya pikir dan persepsi maka akan merubah pola pikir masyarakat sosial di lingkungannya. Besarnya perubahan di masyarakat sangat tergantung dengan banyaknya individu yang mengalami peningkatan pola pikir dan persepsi. Banyaknya individu yang meningkat kualitas daya pikir dan persepsinya akan menggerakkan perubahan struktur sosial dalam masyarakat sosial, sebagaimana nampak pada gambar siklus perubahan struktur dan kultur sosial.

Perubahan meningkatnya kualitas pendidikan masyarakat sosial akan merubah persepsi masyarakat sehingga terjadi transformasi sosial dan berdampak terhadap struktur sosial yang mengubah kultur sosial. Perubah- 
an kultur sosial akan menuntut terjadinya pemberlakuan nilai-nilai, sehingga akan terjadi pemberlakuan tatanan nilai-nilai yang baru. Siklus dalam dinamika tersebut secara tidak langsung menunjukkan posisi fungsi pendidikan dalam pengendalian karakter dan budi pekerti peserta didik dan terhadap tatanan nilai-nilai kehidupan bermasyarakat. Tingkat pendidikan sangat besar pengaruhnya terhadap pemahaman nilai-nilai dan kemampuan pengendalian diri. Semakin tinggi kemampuan pengendalian diri seseorang maka perilakunya cenderung semakin baik, dan nilai kehidupan yang dicerminkan akan semakin tinggi. Mengenai bagaimana proses pewarisan nilai-nilai kehidupan terhadap peserta didik, dan apa saja yang terkait terhadap pendidikan sebagai wahana penanaman nilai-nilai kehidupan akan dijelaskan lebih lanjut pada pembahasan proses penanaman nilai.

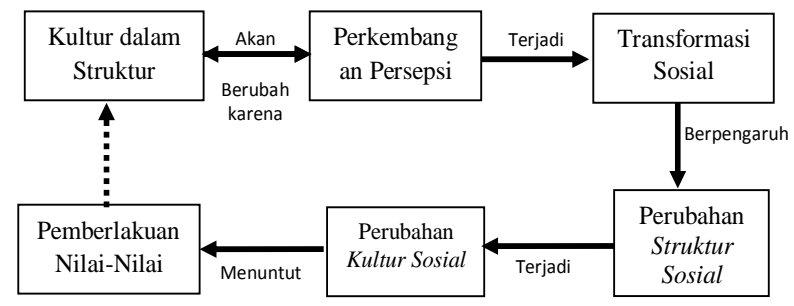

Gambar 1. Dinamika Perubahan Struktur dan Kultur Sosial

Sumber: Yulianto (2013)

\section{Proses Penanaman Nilai}

Nilai bersifat dinamis, berubah sesuai perkembangan zaman yang terjadi. Untuk menjadikan nilai-nilai dapat tetap terpelihara dari generasi ke generasi maka perlu adanya proses internalisasi, proses revitalisasi dan proses pemeliharaan secara terus-menerus. Setiap nilai yang berkembang secara positif dalam lingkungan masyarakat, maka masyarakat itu sendiri akan selalu berusaha mewariskan kepada generasi penerusnya. Demikian akan terjadi terus-menerus sesuai dengan ritme dan dinamika kehidupan yang terjadi dalam masyarakat itu sendiri. Pewarisan nilainilai kehidupan dilakukan melalui media masyarakat dan melalui media pendidikan di sekolah. Setiap individu secara tidak disadari akan menerima warisan nilai-nilai dari para leluhurnya yang telah menjadi kebiasaan, adat, dan budaya masyarakat tempat individu berkembang. Nilai-nilai tersebut secara alamiah akan terinternalisasi pada setiap individu.

Nilai sosial masyarakat merupakan landasan bagi masyarakat untuk merumuskan apa yang benar dan penting, memiliki ciri-ciri tersendiri, dan berperan penting untuk mendorong dan mengarahkan individu agar berbuat sesuai norma yang berlaku. Keterikatan individu terhadap kelompok sosial dialami seseorang sejak kecil. Keterikatan diwaktu kecil berkembang menjadi altruistik, yaitu rasa ikhlas, tanpa pamrih untuk bersikap empati terhadap kondisi lingkungannya. Perkembangannya menjadi suatu keterikatan sikap terhadap lingkungannya. Keterikatan tersebut akan berlawanan dengan rasa egoismenya. Budaya secara proporsional lebih banyak mengembangkan aspek altruisme dari kodrat kita daripada aspek egoisme, (Durkheim, 1990, p. 161). Dengan demikian tidak dapat dihindari lagi bahwa masyarakat dengan segala yang ada akan membentuk norma secara alamiah. Cultural-Determinism ditentukan oleh kebudayaan yang dimiliki oleh masyarakat itu sendiri. Kebudayaan sebagai sesuatu yang turun temurun dari satu generasi ke generasi yang lain, yang kemudian disebut sebagai superorganic. Kebudayaan mengandung keseluruhan pengertian nilai sosial, norma sosial, ilmu pengetahuan serta keseluruhan struktur-struktur sosial, religius, segala pernyataan intelektual dan artistik yang menjadi ciri khas suatu masyarakat. Hal tersebut menunjukkan bahwa pewarisan nilainilai terjadi melalui kehidupan sosial budaya masyarakat. Dalam kehidupan tersebut secara alamiah, setiap hari terus-menerus tanpa disadari terjadi proses pewarisan nilai-nilai dari generasi tua ke generasi yang lebih muda.

Sesungguhnya secara instinktif manusia seperti halnya makhluk lainnya, perilakunya mencari suatu kesenangan, bersifat egoistis. Pada fase prekonfensional perilaku anak merupakan perilaku konatif yang akhirnya menuju volisional. Dari perilaku altruistik pada fase anak-anak akan belajar melakukan sesuatu dengan mengerjakannya. Untuk itu anak harus dirangsang kekuatannya dengan latihan yang efektif, sehingga kesadaran anak akan lebih luas dengan mengenal kelompok. Latihan yang efektif dan bersama kelompok hanyalah dapat dilakukan dengan metode sekolah. Karena di sekolah anak akan mendapatkan lingkungannya yang sesungguhnya, 
dan juga mendapatkan hal-hal baru yang diajarkan di sekolahnya. Tentang isi dari ajarannya, direncanakan dalam program pendidikan yang berupa kurikulum. Pendidikan merupakan proses pengubahan sikap dan tata laku seseorang atau kelompok orang dalam usaha mendewasakan manusia melalui upaya pengajaran dan latihan, proses perbuatan dan cara mendidik.

Dhurkeim menyampaikan bahwa "Education is the socialization of the younger generation", (Falconnet, 1923, p. 529). Pendidikan merupakan media bagi generasi muda untuk sosialisasi. Para orang tua menyediakan sekolah sebagai sarana untuk menjadikan anak-anaknya saling mengenal kehidupan sosial bersama temannya. Di sekolah mereka saling mengenal keterbatasan dari hak kemerdekaannya. Mereka mengenal hak orang lain, mengenal adanya keberlakuan aturan, norma dan budaya. Pendidikan memiliki peran sangat strategis dalam pola perkembangan moral. Sebab tanpa landasan pendidikan, manusia akan banyak dikendalikan oleh dorongan kebutuhan biologisnya belaka ketika hendak menentukan tindakan. Sekolah sebagai lembaga pendidikan memiliki peran yang besar dalam perkembangan moral anak. Dewey menyampaikan, "Education is the growth of mental powers, where growth has involves the increasing harmonization of individuals with society. That harmonization must respect the uniqueness of each person and his capacity for intelligence. Education aims to develop a model democratic society", (Fott, 2009, p. 7). Ada hubungan yang erat antara demokrasi dan pendidikan. Pendidikan berfungsi mendewasakan peserta didik menjadi manusia yang mampu berpartisipasi dalam masyarakat dia berada.

Pendidikan berperan untuk memperbaiki kualitas hidup dari masyarakat di lingkungan peserta didik. Pengenalan terhadap nilai-nilai hidup bersama dilaksanakan apabila peserta didik itu telah dapat memilih sendiri. Menjadi tugas orang tua dan pendidik untuk memperkenalkan peserta didik kepada nilainilai moral yang benar dan menghindarkan diri dari pengaruh masyarakat yang buruk. Ada empat landasan pendidikan nilai yaitu; Landasan filosofis yang mengetengahkan akar pemikiran tentang hakikat manusia dari perspektif filsafat; Landasan psikologis menjelaskan aspek-aspek psikis manusia sebagai indi- vidu; Landasan sosiologis meliputi prinsipprinsip pengembangan manusia sebagai anggota masyarakat; Landasan estetik menguraikan kemampuan manusia dalam mempersepsi nilai keindahan, (Rahmat Mulyana, 2004, p.124). Ideologi-ideologi pendidikan menyiratkan tentang fungsi pendidikan sebagai media penanaman nilai. Khususnya mengenai filosofi pendidikan dengan pendekatan sistem-sistem formal antara lain; Guru adalah pencipta lingkungan pendidikan siswa dan merupakan sumber ilham baginya; Sebuah cara yang penting dan berharga dimana tanggapan siswa dilahirkan adalah melalui kegiatan yang bersifat meniru (imitative) khususnya jika diarahkan oleh para panutan dalam hal karya kreatif serta kepribadian guru yang budiman, (O’Neil, 2008, p. 14).

Telah diuraikan bahwa pewarisan nilai-nilai kehidupan dilakukan melalui media masyarakat dan melalui media pendidikan di sekolah. Sehingga merupakan tugas orang tua dan pendidik di sekolah untuk memperkenalkan peserta didik kepada nilai-nilai moral yang benar dan menghindarkan diri dari pengaruh masyarakat yang buruk. Di lingkungan sekolah mereka saling mengenal keterbatasan dari hak kemerdekaannya. Mereka mengenal hak orang lain, mengenal adanya keberlakuan aturan, norma dan budaya. Pendidikan memiliki peran sangat strategis dalam pola perkembangan moral remaja menuju dewasa. Dengan demikian sangat wajar kalau sekolah merupakan lembaga yang sangat diharapkan sebagai perubah moral dan perilaku. Lalu bagaimana dengan prosesnya, seperti apakah proses yang sebaiknya dijalankan? Berikut akan diuraikan beberapa hal terkait dengan proses perubahan perilaku yang secara umum terjadi pada masa remaja menuju dewasa.

\section{Proses Perubahan Perilaku}

Pemerintah melalui kementerian pendidikan telah menjalankan beberapa kegiatan untuk memperbaiki budi pekerti para peserta didik, kususnya di tingkat SMA/SMK. Kegiatan tersebut diantaranya adalah dengan cara memberikan kesempatan dan pengalaman kepada sebagian peserta didik untuk mengikuti pelatihan dasar kepemimpinan yang dilakukan di lingkungan militer. Bahkan sebagai pelaku pendidik/pelatih adalah anggota militer aktif dengan metode CMI (cara memberikan instruksi) ala militer. Dapat dibayangkan 
seberapa dalam para peserta tersebut mendapatkan "kesan" nilai-nilai kehidupan, khususnya tatanan nilai kehidupan dalam berkomunikasi. Apa yang didapat oleh para pelajar dari pelatihan tersebut, apakah nilai-nilai kehidupan kususnya tentang kedisiplinan, ketertiban, ketegasan dapat mudah diterima dan dijiwai oleh peserta? Ataukah ada penolakan dari dalam jiwa mereka? Seandainya mereka dapat menerima nilai-nilai yang diajarkan dan ditanamkan dalam pelatihan tersebut, apakah mereka dapat langsung menerapkan dalam tindakannya sehari-hari? Rasanya semua itu perlu ada pengkajian lebih dalam.

Di atas telah dijelaskan bahwa setiap anak/individu sesungguhnya telah membawa nilai-nilai sendiri, dan telah memiliki potensi sendiri. Untuk itu dalam penanaman nilai-nilai kehidupan memerlukan waktu untuk pengenalan, pengetahuan, pemahaman, sampai dengan tahap meyakini betul terhadap kebenaran nilai-nilai yang diterimanya. Banyak pendidik berperilaku berdasarkan kebiasaan, tata cara, impuls atau dorongan hati, bukan dengan melandaskan perilaku pada keyakinan-keyakinan intelektual yang serius. Kebanyakan orang mempraktekkan praktek dan bukan mempraktekkan teori. Banyak pendidikan yang tidak mendasarkan pada sebuah filosofis pendidikan yang tertata, sering praktek pendidikan tidak didasarkan pada teori apapun. Dalam prakteknya budi pekerti merupakan bagian dari perilaku. Sering perilaku seseorang tidak didasari oleh pra anggapan ideologis yang jelas ataupun dimotivasi oleh niat ideologis secara sadar. Sehingga dampak dari perilaku sering tidak terkendali, dan sering merugikan diri sendiri maupun orang lain.

O'neill (2008, p. 49) menyebutkan dalam teori perilaku adanya tiga perilaku dasar yaitu; Perilaku konatif adalah perilaku yang secara tersirat memiliki tujuan, namun tidak secara sadar bertujuan semacam itu. Perilaku dimaksud sebagaimana perilaku yang dilakukan oleh bayi (perilaku organismik); Perilaku volisional adalah perilaku konatif yang disadari, di mana individu benar-benar punya tujuan di benaknya; Perilaku normatif adalah perilaku yang diarahkan, secara tersirat ataupun secara gamblang oleh gagasangagasan tertentu (konsep-konsep abstrak atau sudut pandang) yang berkaitan dengan apa yang umumnya dianggap baik atau dikehendaki. Fishben (1975, p. 16) menjelaskan bah- wa sikap dan keyakinan akan membentuk perilaku melalui niat. Sikap akan membentuk perilaku seseorang, tetapi norma subjektif seseorang berpengaruh besar kepada niat untuk membentuk perilaku. Dengan demikian perilaku terbentuk oleh niat yang dipengaruhi oleh sikap dan norma subjektif lingkungannya. Niat seseorang untuk melakukan sesuatu ditentukan oleh dua hal yaitu, sesuatu yang datang dari dalam dirinya sendiri yakni sikap, dan sesuatu yang datang dari luar yakni persepsi tentang pendapat orang lain terhadap dirinya dalam kaitan dengan perilaku yang diperbincangkan.

Para pakar behaviorisme pada umumnya berpendapat bahwa perubahan perilaku melalui berbagai proses yang tahapannya antara lain; berperilaku, berpengalaman, berkeyakinan, pemapanan kepribadian, menjadi filosofi personal, yang akhirnya menjadikan perilaku yang selaras. Untuk itu proses penanaman nilai-nilai harus melibatkan secara langsung kesadaran peserta didik sampai pada tahap akhir. Diharapkan nilai-nilai tersebut dapat terus tertanam dan berkembang dengan baik dalam jiwa individu tersebut. Nilai dapat terpelihara dengan baik oleh individu apabila individu tersebut memiliki kesadaran yang baik terhadap nilai-nilai. Dari pengalaman indera, pengalaman kejiwaan, dan pengalaman religius akan muncul kesadaran diri. Tentang teori kesadaran, Wilber membagi kesadaran manusia dalam 4 (empat) quadrant, yaitu intentional, behavioural, cultural, and Social, (Wilber (1997, p. 5). Kesadaran nilai akan terjaga apabila setiap individu telah mencapai kesadaran integral. Untuk itu proses kegiatan penanaman nilai-nilai kehidupan harus dapat mencapai pada tataran kesadaran integral, yaitu kesadaran yang melibatkan seluruh fungsi indra dan mental manusia. Lebih jauh Wilber menyampaikan bahwa seseorang akan mencapai kesadaran integral apabila sudah melewati tahapan kesadaran melalui mata secara fisik (eye of flesh), mata pikir (eye of mind), dan mata hati (eye of contemplation).

Kesadaran tersebut adalah yang berlangsung dari mata secara fisik (eye of flesh). Dari apa yang dilihat dan dialami secara langsung oleh para siswa akan menjadi pengalaman. Pengalaman inilah yang akan meneruskan kepada ranah pikir, dan menjadi mata pikir (eye of mind) bagi setiap tindakan. Dari pengalaman menjadi pemikiran dan bertindak. 
Dari tindakan-tindakannya pasti akan timbul suatu reaksi. Lepas dari positif dan negatif reaksi tersebut, maka akan menjadi bahan renungan dan sebagai pertimbangan dalam berbagai hal. Sehingga nilai-nilai yang telah diterima dari proses penanaman nilai-nilai tersebut akan menjadi kesadaran yang senantiasa melekat dalam jiwa siswa. Inilah yang disebut dengan berakhir pada mata hati (eye of contemplation).

Penelitian pada suatu lembaga pendidikan membuktikan bahwa nilai-nilai kehidupan yang ditanamkan tersebut berhasil dijiwai oleh peserta didik sampai mereka pensiun, bahkan sampai mereka meninggal. Penelitian tersebut menunjukkan bahwa keberhasilan pendidikan nilai tersebut disebabkan karena memberlakukan siklus pembangkitan kesadaran dalam proses penanaman nilai. Siklus tersebut antara lain, (Yulianto, 2013, p. 360): (a) penanaman nilai secara akademis yang dilanjutkan secara praksis sehingga nilai-nilai kehidupan yang ditanamkan akan menjadi pengetahuan dan pengalaman bagi peserta didik; (b) proses menjadikan pengetahuan dan pengalaman peserta didik tentang nilai kehidupan sebagai pengarah proses berpikir dan bertindak; (c) memberikan kesempatan kepada peserta didik untuk bertindak sesuai dengan nilai-nilai kehidupan yang telah diterimanya; (d) memberikan kesempatan kepada peserta didik untuk merenungkan terhadap reaksi (feedback) dari orang lain atas tindakannya/perilakunya yang sesuai dengan nilai kehidupan yang telah diterimanya; (e) Pengkondisian agar peserta didik mampu merenungkan secara baik dan benar sehingga hasil renungannya dapat menjadi kesadaran jiwanya secara ikhlas; (f) dengan demikian akan terbentuk sikap utuh/integral conciousness.

Siklus tersebut dilalui oleh setiap siswa mulai dari masuk sekolah sampai dengan mereka lulus sekolah. Proses penanaman nilai dilakukan sepanjang hari, dan sepanjang tahun tiada henti. Proses penanaman nilai pada tahap awal ditindaklanjuti dengan daily threatment sampai mereka lulus, sehingga proses dilakukan sepanjang masa di sekolah.

Kesadaran siswa diperoleh karena siswa melihat, dan melakukan sendiri secara langsung terhadap kegiatan proses penanaman nilai-nilai. Kesadaran integral tersebut yang sesungguhnya telah terjadi pada diri para siswa, sehingga segala nilai-nilai yang telah tertanam dalam diri para siswa tidak akan luntur dan tidak akan hilang selama-lamanya. Karena para siswa benar-benar telah melalui tiga proses kesadaran, yaitu eye of flesh, eye of mind, and eye of contemplation. Kesadaran integral yang telah terjadi pada diri siswa tersebut juga disebabkan oleh karena terjadinya perubahan kemampuan logika mereka. Perubahan kemampuan logika dan pengalaman hidup yang telah melintas cenderung berpengaruh terhadap pergeseran nilai-nilai kehidupan yang diberlakukannya. Orang terdidik cenderung mengembang dalam rasio dan menjunjung nilai-nilai kehidupan.

Setelah memperhatikan penjelasan dan uraian tahapan perubahan perilaku tersebut, tentunya perlu menilik terhadap program yang telah dilaksanakan di sekolah-sekolah secara umum. Hanya ada beberapa sekolah yang melakukan proses secara teratur, terarah, dan terus-menerus, dari hari-kehari sepanjang mereka di sekolah dari kelas 1 sampai dengan lulus. Bagaimana dengan sekolah yang tidak mengikuti siklus tersebut, tanpa tahapan tersebut apa bisa berubah/apa bisa memperbaiki perilaku peserta didik? Dengan waktu yang relatif sebentar, kapan mereka punya waktu untuk merenungkan, kapan mereka mendapatkan feedback, kapan mereka menyadari, kapan mereka dikondisikan untuk terjaga perilakunya, sedangkan pada kenyataannya secara umum guru sering kurang peduli terhadap perkembangan perilaku siswa. Dengan kegiatan yang hanya sepotong dikhawatirkan malah membuat peserta didik merasa super dan menjadi sombong (telah mengikuti pendidikan dasar kemiliteran). Kesombongan menjadikan gesekan terhadap sesama peserta didik, yang akhirnya dapat menimbulkkan perkelahian. Semua itu perlu dikaji lagi, setiap program harus diperhatikan dan diupayakan untuk ketuntasan pelaksanaan dan penanganannya.

\section{SIMPULAN}

Dari penjelasan-penjelasan yang telah disampaikan, secara umum dapat disimpulkan sebagai berikut: (a) edukasi terhadap anak yang dilakukan di sekolah, kelompok, dan masyarakat sosial hendaknya dapat dihindarkan dari segala bentuk abuse. Dalam proses edukasi dan pembentukan karakter hendaknya 
menghindari pemaksaan kehendak dengan menggunakan abuse; (b) pembentukan karakter yang salah satunya diprogramkan oleh pemerintah dengan menitipkan di instansi/ lembaga militer perlu dikaji ulang secara mendalam; (c) Proses pendidikan karakter dan pengelolaan perilaku akan lebih berhasil apabila mengikuti beberapa tahapan, pengelolaan kesadaran integral; d) Meningkatkan altruistnya siswa untuk menjadikan ikatan terhadap nilai-nilai kehidupan yang diajarkan menjadi perilakunya, sehingga mencapai tahapan integral consciousness dan menjadi sikap utuh dari peserta didik

\section{DAFTAR PUSTAKA}

Budiyono, K. (2007). Nilai-nilai kepribadian dan kejuangan bangsa Indonesia. Bandung: Alfa Beta.

Durkheim, E. (1990). Pendidikan moral, suatu studi teori dan aplikasi sosiologi pendidikan. (Judul asli: Moral Education: 1961). Jakarta: Erlangga.

Falconnet, Paul. (1923). The pedagogical work of Emile Durkheim. (American Journal of Sociology). Chicago: The University of chicago Press.

Fishben. (1975). Belief, attitude, intention and behavior, an introduction to theory and research. Philipines: AddisonWesley.

Fott, David. (2009). John Dewey and the mutual influence of democracy and education. Cambridge University Press.

Mulyana, R. (2004). Mengartikulasikan pendidikan nilai. Bandung: Alfabeta.

O'Neil, William. (2008). Ideologi-ideologi pendidikan. Yogyakarta: Pustaka Pelajar.

Patching, K, (2007). Leadership, character and strategy. New York: Palgrave Macmillan.

Ritzer, G \& Goodman, DJ. (2009). Teori sosiologi, dari teori sosiologi klasik sampai perkembangan mutakhir teori sosial postmodern. Yogyakarta: Kreasi Wacana.

Sugiharto, B. (2008). Humanisme dan humaniora relevansinya bagi pendidikan. Yogyakarta: Jalasutra.

Wilber, K. (1997). An Integral theory of conciousness Journal of Conciousness Studies. Imprint Academic.

Yulianto. (2013). Penanaman nilai-nilai bela negara kadet maguwo dalam perspektif historis. Yogyakarta: UNY. 